Article

\title{
New Taxa of the Family Amniculicolaceae (Pleosporales, Dothideomycetes, Ascomycota) from Freshwater Habitats in Spain
}

\author{
Viridiana Magaña-Dueñas, Alberto M. Stchigel * and José F. Cano-Lira \\ Mycology Unit, Medical School and IISPV, Universitat Rovira i Virgili, Sant Llorenç 21, \\ 43201 Reus, Tarragona, Spain; qfbviry@hotmail.com (V.M.-D.); jose.cano@urv.cat (J.F.C.-L.) \\ * Correspondence: albertomiguel.stchigel@urv.cat; Tel.: +34-626-525-611
}

Received: 12 August 2020; Accepted: 3 September 2020; Published: 4 September 2020

check for updates

\begin{abstract}
With the exception of the so-called Ingoldian fungi, the diversity and distribution of the freshwater aero-aquatic or facultative fungi are not well known in Spain. In view of that, we collected and placed into wet chambers 105 samples of submerged and decomposing plant debris from various places in Spain, looking for individuals belonging to these latter two morpho-ecological groups of fungi. As a result, we found and isolated in pure culture several fungi, the morphology of some of them belonging to the family Amniculicolaceae (order Pleosporales, class Dothideomycetes). After a careful phenotypic characterization and a phylogenetic tree reconstruction using a concatenated sequence dataset of D1-D2 domains of the 28S nrRNA gene ( $L S U$ ), the internal transcribed spacer region (ITS) of the nrDNA, and a fragment of the translation elongation factor 1-alpha (tef1) gene, we report the finding of three new species of the genus Murispora: Murispora navicularispora, which produces cinnamon-colored, broadly fusiform to navicular ascospores; Murispora fissilispora, which has as a remarkable characteristic the production of both sexual and asexual morphs in vitro; and Murispora asexualis, the unique species of the genus that lacks a sexual morph. As a consequence of the phylogenetic study, we introduce the new aero-aquatic genus Fouskomenomyces, with a new combination (Fouskomenomyces cupreorufescens, formerly Spirosphaera cupreorufescens as the type species of the genus) and a new species, Fouskomenomyces mimiticus; we propose the new combinations Murispora bromicola (formerly Pseudomassariosphaeria bromicola) and Murispora triseptata (formerly Pseudomassariosphaeria triseptata); and we resurrect Massariosphaeria grandispora, which is transferred to the family Lopiostomataceae.
\end{abstract}

Keywords: Ascomycota; freshwater; fungi; plant debris; Pleosporales; Spain

\section{Introduction}

Fungi are a diverse group of ubiquitous organisms present in almost all ecosystems on Earth, including aquatic habitats [1]. Several fungal taxa have been isolated from freshwater environments, which offer a wide range of organic substrates for fungal colonization [2]. The most important role of fungi in freshwater is the recycling of dead organic matter, typically submerged plant debris [3]. Freshwater fungi complete (at least one part of) their life cycle into the water, and disperse their propagules through the water. Freshwater fungi are generally classified into different sorts of morphological and ecological groups: the "Ingoldian", producing submerged star-like (stauro-) or worm-like (scoleco-) asexual spores (or propagules) in lotic habitats (moving waters) [2,4]; the aero-aquatic, forming helical, net-like or globose conidia above the surface of lentic (standing) waters [5]; and members of the Ascomycota reproducing by the formation of conidia or sexual propagules (ascospores) into fertile bodies (conidiomata and ascomata, respectively). Members of 
the Ascomycota reproducing by ascospores seem to be less exclusively adapted to life in aquatic environments than the other sort of previously cited fungal groups [6]. These fungi produce unitunicate asci with apical structures, or these are fissitunicate (bitunicate) and the ascospores are mostly ornate with mucilaginous sheaths or appendages which facilitate the attachment to submerged substrates [7].

The freshwater Ascomycota (FWA) are one of the least studied groups of fungi but they are taxonomically diverse and have representatives in a wide spectrum of families and orders. Approximately one third of the FWA with sexual reproduction belongs to the class Dothideomycetes [8]. Four lineages of the class Dothideomycetes have been recently described from this habitat: the order Jahnulales [9], the family Lindgomycetaceae [10,11], the family Natipusillaceae [12] and the family Amniculicolaceae $[13,14]$. The latter was established by Zhang in 2009 [15] to accommodate the genera Amniculicola, Murispora and Pseudomassariosphaeria [15]. Although all species of those three genera grow and produce a purple pigment on submerged wood, they differ in the morphology of the ascospores, which vary in color (hyaline in Amniculicola, and brown in Murispora and in Pseudomassariosphaeria) and septation (1-septate in Amniculicola, transversely multiseptate in Pseudomassariosphaeria, and with multiple transversal, longitudinal and oblique septa (muriform) in Murispora) [15,16]. Most of the Amniculicolaceae have been reported from freshwater habitats in Italy, France, Germany, Denmark and China [15-18].

During a survey on fungi living on decaying plant material in freshwater habitats in Spain, several strains that are morphologically compatible with members of the family Amniculicolaceae have been isolated in pure culture. The objectives of this study were to characterize phenotypically and to identify such fungi by phylogenetic analysis using nucleotide sequences of informative molecular markers.

\section{Materials and Methods}

\subsection{Sample Collection and Specimen Examination}

A total of 105 samples of submerged plant material were collected: three in Les Guilleries (Barcelona province), 50 in Cascadas del Huéznar (Cazalla de la Sierra, Sevilla province), 22 in Capafonts (Tarragona province) and 30 in Serra del Montsant (Tarragona province), Spain. These were placed into sterile self-sealing plastic bags to be transported to the lab and stored until processing. The specimens were rinsed twice with tap water, placed into Petri dishes or appropriate plastic containers lined inside with filter paper and moistened with sterile water with diehldrin ${ }^{\circledR}(20$ drops of a solution of $20 \mathrm{mg}$ diehldrin in $20 \mathrm{~mL}$ of dimethyl-ketone/L of water), incubated at room temperature $\left(20-25^{\circ} \mathrm{C}\right)$, and examined periodically under stereomicroscope for up to 2 months. Several ascomata or asexual propagules were taken and transferred using sterile disposable tuberculin-type needles to $55 \mathrm{~mm}$ diam. Petri dishes containing oatmeal agar (OA; $30 \mathrm{~g}$ of filtered oat flakes, $15 \mathrm{~g}$ agar-agar, $1 \mathrm{~L}$ tap water [19]), then incubated at room temperature. All isolates were stored in the culture collection of the Faculty of Medicine at Universitat Rovira i Virgili (FMR; Reus, Spain). Type specimens and ex-type cultures of the novel fungi were deposited in the Westerdijk Fungal Biodiversity Institute (CBS), Utrecht, The Netherlands (Table 1).

Table 1. Fungal taxa and their nucleotide sequences of the molecular markers used to build the phylogenetic tree.

\begin{tabular}{ccccc}
\hline \multirow{2}{*}{ Taxon } & \multirow{2}{*}{ Strain } & \multicolumn{2}{c}{ GenBank Accession No. } \\
\cline { 3 - 5 } & & LSU & ITS & tef1 \\
\hline Amniculicola lignicola & CBS 123094 & MH874798 & - & GU456278 \\
Amniculicola longissima & CB L22 & GU266240 & AY204596 & - \\
Amniculicola lonsissima & CCM-F10304 & JN673029 & AY204594 & - \\
Amniculicola parva & CBS 123092 & FJ795497 & MH863272 & GU349065 \\
Fouskomenomyces cupreorufescens & A20 & AY616236 & AY616232 & - \\
\hline
\end{tabular}


Table 1. Cont.

\begin{tabular}{|c|c|c|c|c|}
\hline \multirow{2}{*}{ Taxon } & \multirow{2}{*}{ Strain } & \multicolumn{3}{|c|}{ GenBank Accession No. } \\
\hline & & LSU & ITS & tef1 \\
\hline Fouskomenomyces mimiticus & FMR $16,958^{\mathrm{T}}$ & LR824585 & LR824586 & LR824584 \\
\hline Fouskomenomyces mimiticus & FMR 17,151 = CBS 146935 & LR824588 & LR824587 & LR824589 \\
\hline Leptosphaeria dolium & CBS 125979 & JF740283 & JF740208 & - \\
\hline Leptosphaeria dolium & CBS 505.75 & GQ387576 & JF740205 & GU349069 \\
\hline Lindgomyces ingoldianus & ATCC $200398^{\mathrm{T}}$ & AB521736 & JF419898 & - \\
\hline Lindgomyces rotundatus & KT966 & AB521739 & JF419901 & - \\
\hline Lophiostoma macrostomum & CBS 122681 & EU552141 & EU552141 & LC001753 \\
\hline Lophiostoma arundinis & KT 651 & AB618999 & JN942965 & LC001738 \\
\hline Massariosphaeria grandispora & CBS 613.86 & FJ795507 & - & GU349036 \\
\hline Murispora aquatica & MFLU $19-0990^{\mathrm{T}}$ & MN325075 & MN325085 & MN337969 \\
\hline Murispora asexualis & FMR $17,248^{\mathrm{T}}=$ CBS 146937 & LR824596 & LR824593 & LR824590 \\
\hline Murispora bromicola & MFLUCC 15-0031 & NG_059595 & NR_164235 & КT305999 \\
\hline Murispora cardui & MFLUCC $13-0761^{\mathrm{T}}$ & NG_059607 & KT736082 & KT709190 \\
\hline Murispora cicognanii & MFLUCC 14-0953 ${ }^{\mathrm{T}}$ & NG_059609 & NR_155381 & MK109804 \\
\hline Murispora fagicola & MFLUCC $13-0600^{\mathrm{T}}$ & NG_060797 & NR_155379 & KT709188 \\
\hline Murispora fissilispora & FMR $17,251^{\mathrm{T}}=$ CBS 146936 & LR824597 & LR824594 & LR824591 \\
\hline Murispora galii & MFLUCC $13-0819^{\mathrm{T}}$ & KT709175 & NR_154629 & KT709189 \\
\hline Murispora haswksworthii & MFLUCC $14-091^{\mathrm{T}}$ & KT709180 & NR_138414 & KT709192 \\
\hline Murispora medicaginicola & MFLUCC $13-0762^{\mathrm{T}}$ & NG_059609 & NR_155380 & KT709191 \\
\hline Murispora navicularispora & FMR $17,838^{\mathrm{T}}$ & LR824598 & LR824595 & LR824592 \\
\hline Murispora rubicunda & IFRD $2017^{\mathrm{T}}$ & FJ795507 & - & GU456289 \\
\hline Murispora triseptata & MF1336 & MK411002 & - & - \\
\hline Neomassariosphaeria typhicola & $\mathrm{KT} 797^{\mathrm{T}}$ & AB521747 & JF419906 & - \\
\hline Preussia lignícola & CBS 264.69 & MH878448 & - & GU349027 \\
\hline Preussia minima & CBS 524.50 & MH868263 & MH856741 & DQ677897 \\
\hline Quadricrura septentrionalis & CBS 125430 & MH875152 & NR_119402 & - \\
\hline Triplosphaeria máxima & KT 870 & AB524637 & NR_119407 & - \\
\hline Tetraplosphaeria sasicola & $\mathrm{KT} 563^{\mathrm{T}}$ & AB524631 & AB524807 & - \\
\hline Vargamyces aquaticus & CBS $636.9^{\mathrm{T}}$ & KY853539 & NR_154471 & - \\
\hline Vargamyces aquaticus & FMR 11587 & KY853538 & KY853475 & - \\
\hline Vargamyces aquaticus & FMR 16,953 & LR812096 & LR812095 & - \\
\hline Westerdykella ornata & CBS $379.55^{\mathrm{T}}$ & NG_057861 & NR_103587 & GU349021 \\
\hline
\end{tabular}

${ }^{1}$ A20: Hermann Volgmayr; ATCC: American Type Culture Collection, Virginia, USA; CB: Christiane Baschien; CBS: Culture collection of the Westerdijk Biodiversity Institute, Utrech, The Netherlands; CCM: Czech Collection on Microorganisms, Masaryk University, Faculty of Science, Brno, Czech Republic; FMR: Facultat de Medicina, Reus, Spain; IFRD: IFRDCC: Culture Collection, International Fungal Research \& Development Centre, Chinese Academy of Forestry, Kunming, China; KT: Kazuaki Tanaka; MFLUCC: Mae Fah Luang University Culture Collection, Chiang Rai, Thailand. ${ }^{2}$ Strains studied by us are indicated in bold. ${ }^{\mathrm{T}}$ Ex-type strain.

\subsection{Phenotypic Study}

Macroscopic characterization of the colonies was performed on OA, $2 \%$ malt extract agar (MEA; Difco, Detroit, MI, USA) [19] and potato dextrose agar (PDA; Pronadisa, Madrid, Spain) [20] into $90 \mathrm{~mm}$ diam. Petri dishes, after incubation for three weeks at $15{ }^{\circ} \mathrm{C}$ in the dark for species of the genus Murispora [16], and in similar conditions but at $20^{\circ} \mathrm{C}$ for other taxa. Color notations were according to Kornerup and Wanscher (1978) [21]. The ability of the isolates to grow at cardinal temperatures was determined on PDA after $7 \mathrm{~d}$ in the dark, ranging from 5 to $35^{\circ} \mathrm{C}$, at $5{ }^{\circ} \mathrm{C}$ intervals, but also at $37{ }^{\circ} \mathrm{C}$. Measurements and descriptions of microscopic structures were taken from specimens mounted in Shear's mounting medium (3 g potassium acetate, $60 \mathrm{~mL}$ glycerol, $90 \mathrm{~mL}$ ethanol $95 \%$ and $150 \mathrm{~mL}$ distilled water) [22], using an Olympus BH-2 bright field microscope (Olympus Corporation, Tokyo, Japan). Photomicrographs were taken using a Zeiss Axio-Imager M1 microscope (Oberkochen, Germany) with a DeltaPix Infinity $\times$ digital camera using Nomarski differential interference contrast. 


\subsection{DNA Extraction PCR Amplification and Sequencing}

The strains were cultured on PDA for 7 days at $25^{\circ} \mathrm{C}$ in the dark. Total DNA was extracted using the FastDNA kit protocol (Bio101, Vista, CA, USA), with a FastPrep FP120 instrument (Thermo Savant, Holbrook, NY, USA) according to the manufacturer's protocol. DNA was quantified by using Nanodrop 2000 (Thermo Scientific, Madrid, Spain). The following loci were amplified and sequenced: LSU (28S nrRNA gene), with the primer pair LR0R [23] and LR5 [24]; ITS (internal transcribed spacer region), with the primer pair ITS5 and ITS4 [25]; and tef1 with EF1-983F and EF1-2218R [26]. The PCR amplifications were performed in a total volume of $25 \mu \mathrm{L}$ containing $5 \mu \mathrm{L} 10 \times$ PCR Buffer (Invitrogen, CA, USA), $0.2 \mathrm{mM}$ dNTPs, $0.5 \mu \mathrm{L}$ of each primer, $1 \mathrm{U}$ Taq DNA polymerase and 1-10 ng genomic DNA. PCR conditions for LSU and ITS were set as follows: an initial denaturation at $95^{\circ} \mathrm{C}$ for $5 \mathrm{~min}$, followed by 35 cycles of denaturation, annealing and extension, and a final extension step at $72{ }^{\circ} \mathrm{C}$ for $10 \mathrm{~min}$. For the LSU and ITS amplification, the 35 cycles consisted of $45 \mathrm{~s}$ at $95{ }^{\circ} \mathrm{C}, 45 \mathrm{~s}$ at $53{ }^{\circ} \mathrm{C}$ and $2 \mathrm{~min}$ at $72{ }^{\circ} \mathrm{C}$; and for the tef1 an initial denaturation at $94{ }^{\circ} \mathrm{C}$ for $2 \mathrm{~min}$, followed by 30 cycles consisting of $30 \mathrm{~s}$ at $94^{\circ} \mathrm{C}, 1 \mathrm{~min} 20 \mathrm{~s}$ at $57^{\circ} \mathrm{C}$ and $1 \mathrm{~min} 30 \mathrm{~s}$ at $72{ }^{\circ} \mathrm{C}$. PCR products were purified and stored at $-20^{\circ} \mathrm{C}$ until sequencing. The same pairs of primers were used to obtain the sequences at Macrogen Spain (Macrogen Inc., Madrid, Spain). The consensus sequences were obtained using the SeqMan software v. 7 (DNAStar Lasergene, Madison, WI, USA).

\subsection{Phylogenetic Analysis}

The sequences generated in this study were compared with those of the National Center for Biotechnology Information (NCBI) using the Basic Local Alignment Search Tool (BLAST; https://blast.ncbi.nlm.nih.gov/Blast.cgi). Alignment for each locus was performed with the MEGA (Molecular Evolutionary Genetics Analysis) software v. 7.0. [27], using the ClustalW algorithm [28] and refined with MUSCLE [29] or manually, if necessary, on the same platform. The alignment included our sequences, together with those available at the NCBI databases, of all genera and species belonging to the family Amniculiculaceae, and representatives of the families Lindgomytaceae, Teratospharriaceae, Lophiostomataceae and Sporormiaceae (Table 1). The phylogenetic analyses were carried out using Maximum-Likelihood (ML) and Bayesian Inference (BI) with RAxML v. 8.2.10 [30] using the Cipres Science gateway portal [31] and MrBayes v. 3.2.6 [32], respectively. For ML analyses, the best nucleotide substitution model was General Time Reversible with Gamma distribution. Support for internal branches was assessed by 1000 ML bootstrapped pseudoreplicates. For the BI phylogenetic analysis, the best nucleotide substitution model was determined using jModelTest [33]. For ITS, we used the symmetrical model with gamma distribution (SYM + G), for $L S U$, we used the symmetrical model with proportion of invariable sites and gamma distribution (SYM + I + G), and for tef1, we used the General Time Reverse with proportion of invariable sites and gamma distribution $(G T R+I+G)$. The parameter settings were two simultaneous runs of 5M generations, four Markov chain Monte Carlo (MCMC), sampled every 1000 generations. The 50\% majority-rule consensus tree and posterior probability values were calculated after discarding the first 25\% of the samples. Leptosphaeria dolium (CBS 125,979 and CBS 505.75) served as outgroup taxa. Confident branch support was defined as Bayesian posterior probabilities (PP) $\geq 0.95$ and ML bootstrap support (BS) $\geq 70 \%$. Sequences generated in this study were deposited in European Nucleotide Archive (ENA).

\section{Results}

\subsection{Phylogenetic Analyses}

The final concatenated ITS-LSU-tef1 sequence dataset using both ML and Bayesian analyses contained 37 ingroup strains from five families (Amniculicolaceae, Lindgomytaceae, Lophiostomataceae, Sporormiaceae and Teratospharriaceae). The alignment comprised a total of 1936 characters including gaps (815 for LSU, 399 for ITS and 722 for tef1), of which 435 were parsimony informative (125 for LSU, 173 for ITS and 137 for tef1). The individual sequence datasets did not show any conflicts in the tree 
topologies for the $70 \%$ reciprocal bootstrap trees, which allowed the three genes for the multi-locus analysis to be combined. The ML analysis showed similar tree topology and was congruent with that obtained in the Bayesian analysis. For the BI multi-locus analysis, a total of 2706 trees were sampled after the burn-in with a stop value of 0.01 . The support values were slightly different with the two analysis methods: with BI, posterior probabilities being higher than the ML bootstrap support values. In our phylogenetic analysis, the family Amniculicolaceae formed a well-supported main clade (99\% BS/1 PP) (Figure 1). All taxa in this family were split into two well-supported clades. The first one (99\% BS/1 PP) included two accepted genera (Amniculicola, 96\% BS/1 PP and Vargamyces, 91\% BS/1 PP), plus another genus (81\% BS/0.98 PP). We propose this one as the new Fouskomenomyces, comprising Fouskomenomyces cupreorufescens (basionym Spirosphaera cupreorufescens) and two of our strains (FMR 17,151 and FMR 16,958). The second main clade, corresponding to the genus Murispora (94\% BS/1 PP), was represented by all previously described species (including the type species of the genus, M. rubicunda). Our strains FMR 17,248, FMR 17,251 and FMR 17,838 were placed into independent terminal branches, each one representing a new species for the genus and two new combinations, M. bromicola (basionym Pseudomassariosphaeria bromicola) and M. triseptata (basionym P. triseptata). Surprisingly, Pseudomassariosphaeria grandispora (formerly included in the Amniculicolaceae) fell into the Lopiostomataceae (96\% BS/1 PP).

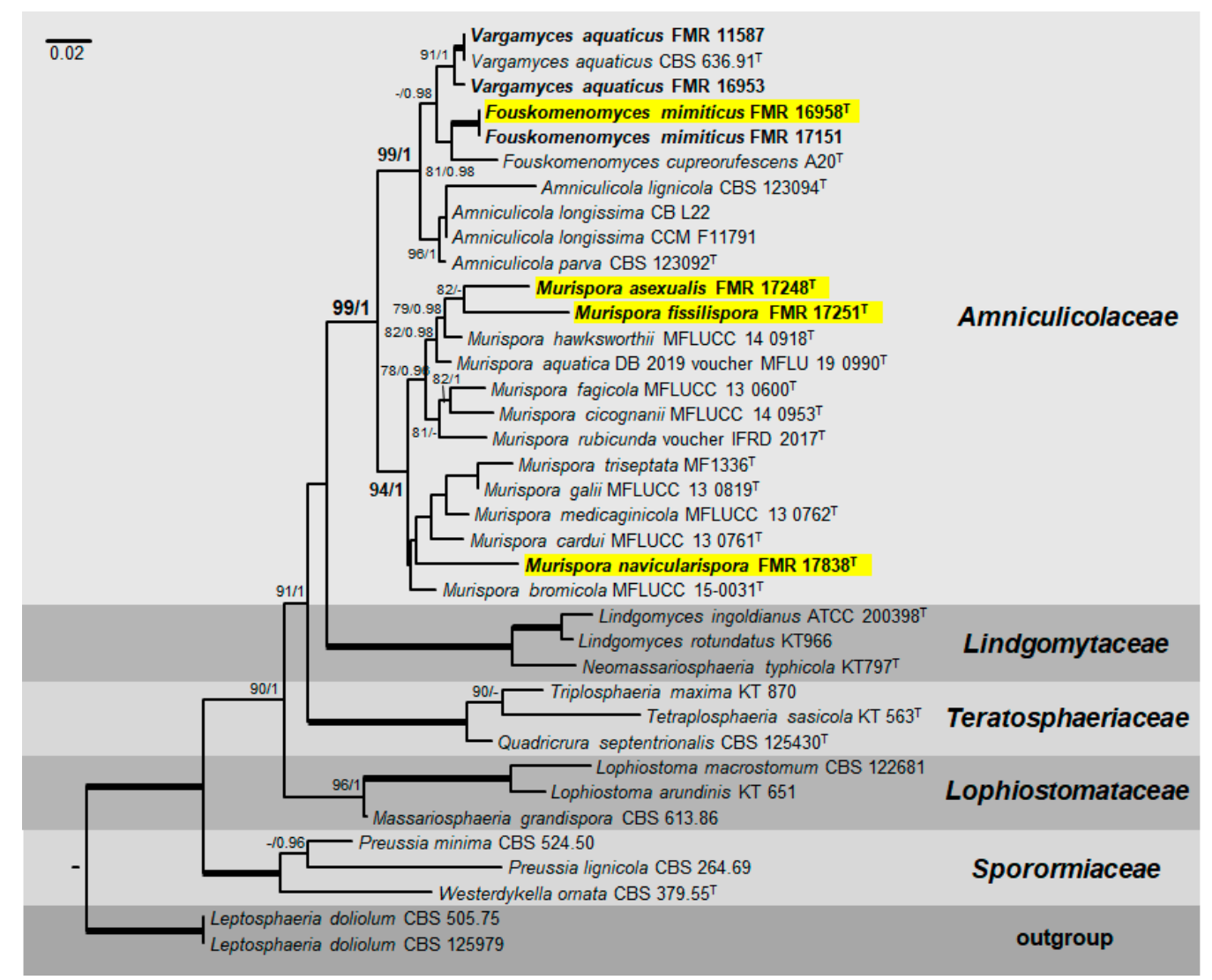

Figure 1. Phylogenetic tree inferred from a maximum likelihood analysis based on a concatenated alignment of D1-D2 domains of the 28S nrRNA gene (LSU), the internal transcribed spacer region (ITS) of the nrDNA, and a fragment of the translation elongation factor 1-alpha (tef1) gene sequences of 37 strains representing species in Amniculicolaceae, Lindgomytaceae, Lophiostomataceae, Sporormiaceae and Teratosphaeriaceae. The Bayesian posterior probabilities (PP) above 0.95 and the RAxML bootstrap support values (BS) above 70\% are given at the nodes (PP/BS). Fully supported branches (1 PP/100 BS) are indicated in bold. Strains isolated during the developing of this work are in bold. Newly proposed taxa are highlighted in a yellow background. Type strains are indicated by a superscript " $\mathrm{T}$ ". The tree was rooted with Leptosphaeria dolium (CBS 125,979 and CBS 505.75). Alignment length 1,936 bp. 


\subsection{Taxonomy}

Amniculicolaceae Y. Zhang ter, C.L. Schoch, J. Fourn., Crous \& K.D. Hyde, Studies in Mycology 64: 95 (2009). MycoBank 515469.

Type genus: Amniculicola Y. Zhang ter \& K.D. Hyde, Mycol. Res. 112(10):1189 (2008).

Because Spirosphaera cupreorufescens was placed into a terminal clade in the Amniculicolaceae, and the type species of the genus, Spirosphaera floriformis, is phylogenetically distant (in the class Leotiomycetes [34]), and our strains FMR 16,958 and FMR 17,151 grouped together on a sister branch in the same terminal clade as S. cupreorufescens, we erect the new genus Fouskomenomyces, and recognize two species: Fouskomenomyces cupreorufescens comb. nov. (the type species of the genus) and Fouskomenomyces mimiticus sp. nov.

Fouskomenomyces V. Magaña-Dueñas, Cano \& Stchigel, gen. nov. MycoBank MB835696.

Etymology. From Greek $\varphi о v \sigma \kappa \omega \mu \varepsilon \varepsilon v o-$, inflated, and $-\mu v \kappa \kappa \eta \tau \alpha$, fungus, because of the nature of the propagules.

Description: Mycelium superficial to immersed composed by septate, smooth- and thin-walled, hyaline to pale brown, branching hyphae. Conidiophores micronematous to semi-macronematous, simple, pale brown, conidiogenous cells integrated, holoblastic, polyblastic. Conidial propagules brown to copper brown, more or less globose, scattered, composed by a compact branched system of globose to polyhedral cells, each one blown out successively to produce several daughter cells, detached by rhexolytic secession, or formed by branched, loosely spirally, interwoven septate filaments. Chlamydospores and sexual morph not observed.

Type species: Fouskomenomyces cupreorufescens (Voglmayr 2004) V. Magaña-Dueñas, Stchigel \& Cano. MycoBank MB 835697.

Fouskomenomyces cupreorufescens (Voglmayr 2004) V. Magaña-Dueñas, Stchigel \& Cano, comb. nov. MycoBank MB 835697.

Basionym: Spirosphaera cupreorufescens Voglmayr, Studies in Mycology 50:221-228. (2004).

Description: Voglmayr (2004).

Notes: The main distinctive features of F. cupreorufescens are its production of coppery-brown conidia in mass, irregularly globose and up to $150 \mu \mathrm{m}$ diam. and its branched, loosely spiralled, interwoven, septate filaments.

Fouskomenomyces mimiticus V. Magaña-Dueñas, Cano \& Stchigel, sp. nov. FMR 16,958. Mycobank MB 835698. (Figure 2)

Etymology. From Greek $\mu \iota \eta \eta \tau \iota k o ́ \varsigma$, mimetic, because the morphological resemblance to other genera such as Pseudoagerita.

Description: Mycelium superficial to immersed, composed by septate, smooth- and thin-walled, pale brown, branched, $2-3 \mu \mathrm{m}$ wide hyphae. Conidiophores micronematous to semi-macronematous, simple, pale brown, conidiogenous cells integrated, polyblastic. Conidial propagules brown, globose to sub-globose, 55-150 $\mu \mathrm{m}$ diam., composed by a compact branched system of globose to polyhedral cells of $4-5 \mu \mathrm{m}$ diam., each one successively budding out up 3-5 daughter cells, not breaking up into fragments when old, and detaching from the hyphae by rhexolytic secession. Chlamydospores and sexual morph absents.

Culture characteristics (after 3 weeks at $20^{\circ} \mathrm{C}$ ): Colonies on natural substratum not evident, appearing as scattered propagules. Colonies on MEA $2 \%$ reaching $25 \mathrm{~mm}$ diam., velvety, umbonate, margins regular, with abundant aerial mycelium, orange white to brownish-orange (6C4); reverse dark brown to brown (7F8/7E8), orange white (6C4) at the margins. Colonies on OA reaching 34-36 mm diam., flattened, slightly floccose, margins regular, with sparse aerial mycelium, dark purple to purplish grey (14F6/14B2); reverse violet to grey (15E8/14D1/15A3), margins white (1A1). Colonies on PDA reaching $28 \mathrm{~mm}$ diam., convex, cottony at the center, slightly floccose and velvety in the rest of the colony, margins regular, pinkish-white (9A2), margins orange grey (6B2); reverse brownish orange to reddish brown (6C3/8E7), margins orange white (5A2). Cardinal temperatures of growth: Optimum $20^{\circ} \mathrm{C}$, maximum $28^{\circ} \mathrm{C}$, minimum $15^{\circ} \mathrm{C}$. 

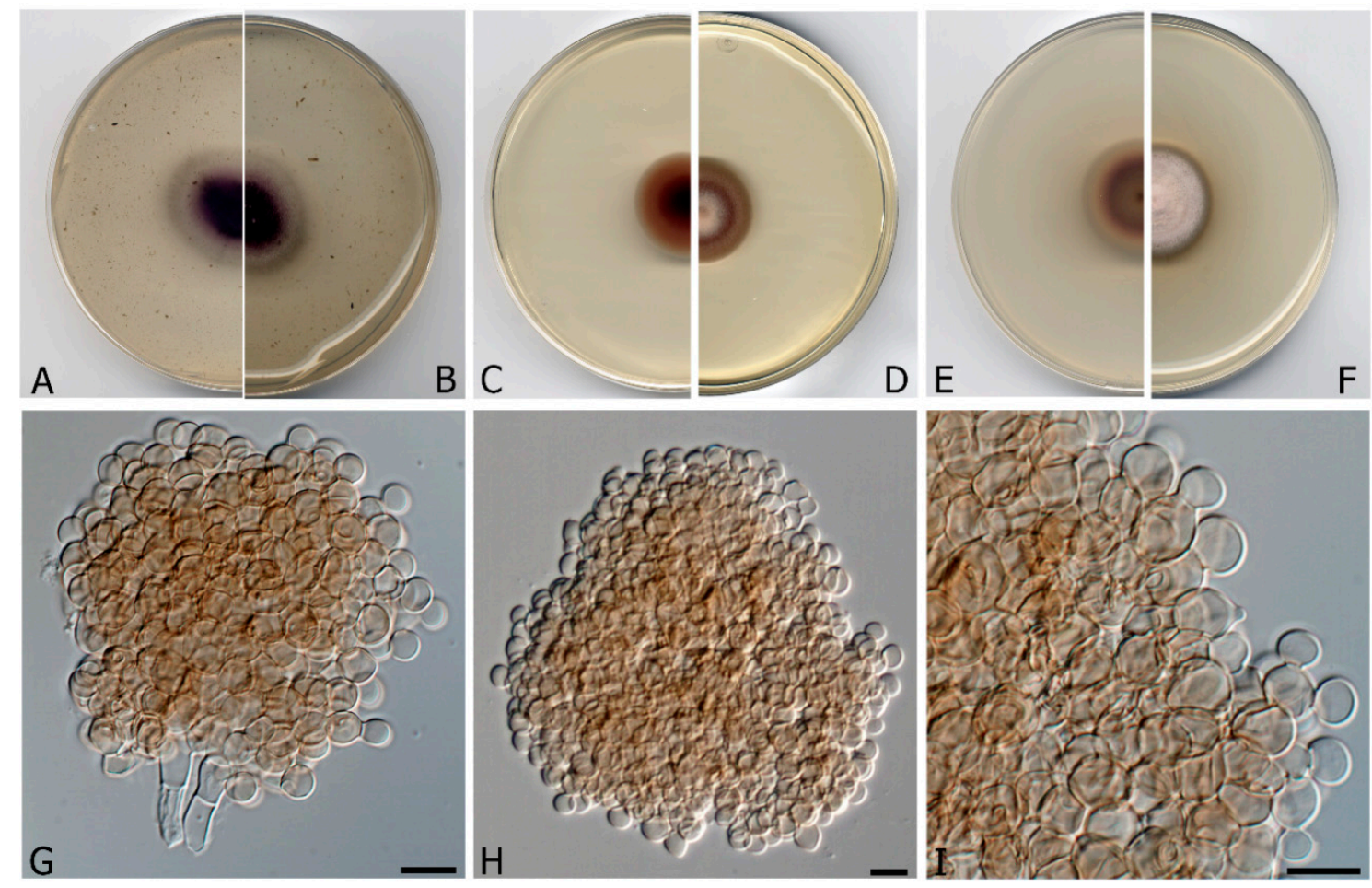

Figure 2. Fouskomenomyces mimiticus CBS H-24461. (A,B) Colonies on OA (oatmeal agar; reverse and front), (C,D) MEA (malt extract agar) 2\% (reverse and front), (E,F) PDA (potato dextrose agar; reverse and front), at $20{ }^{\circ} \mathrm{C}$ after 3 weeks. (G) Conidial propagules with attached conidiogenous cells. (H) Free propagule. (I) Detail of a propagule showing the budding-like cells. Scale bars $=10 \mu \mathrm{m}$.

Material examined: Spain, Barcelona province, Les Guilleries, from freshwater submerged plant debris, Nov. 2017, Eduardo Jose de Carvalho Reis, holotype CBS H-24461, culture ex-type FMR 16,958. Spain, Barcelona province, Les Guilleries, from freshwater submerged plant debris, Nov. 2017, Eduardo Jose de Carvalho Reis, living cultures FMR 17,151 = CBS 146935.

Notes: Fouskomenomyces mimiticus produces brown to dark brown, globose to sub-globose propagules, composed of a compact branched system of globose to polyhedral cells, whereas the propagules of Fouskomenomyces cupreorufescens are formed by branched, loosely spiralled, interwoven filaments, which are coppery-brown in mass.

Because the genus Murispora now includes three new species and two new combinations (Figure 1) displaying novel morphological features, we have amended it as follows:

Murispora Y. Zhang ter, J. Fourn. \& K.D. Hyde, in Zhang et al., Stud. Mycol. 64: 95 (2009). MycoBank MB 515472.

Saprobic fungi living in freshwater habitats. Ascomata scattered or in small groups, immersed, erumpent, or nearly superficial, dark brown to black, ostiolate, globose to subglobose, neck periphysate with an apex weakly papillate, conical or nearly so. Peridium 3-7-layered, outer layer of textura angularis or textura intricata. Pseudoparaphyses trabeculate, embedded in mucilaginous material. Asci (4-)8-spored, bitunicate, fissitunicate, short pedicellate, cylindrical to clavate, with an ocular chamber. Ascospores transversally septate or muriform, hyaline when young, mostly becoming pale brown to reddish brown with age, less commonly remaining hyaline, constricted at the septa, navicular to broadly ellipsoidal, usually surrounded by an irregular, hyaline, gelatinous sheath. Staining the substrate in purple. Asexual morph coelomycetous. 
Type species: Murispora rubicunda (Niessl) Y. Zhang ter, J. Fourn. \& K.D. Hyde, in Zhang et al., Stud. Mycol. 64: 96 (2009).

$\equiv$ Pleospora rubicunda Niessl, Notiz. Pyr.: 31 (1876).

$=$ Massariosphaeria rubicunda (Niessl) Crivelli, Ueber die heterogene Ascomycetengattung pleospora rabh.; Vorschlag für eine Aufteilung (Diss. Eid genössischen technischen hochschule Zürich 7318): 144 (1983).

= Karstenula rubicunda (Niessl) M.E. Barr, N. Amer. Fl., Ser. 2 (New York) 13: 52 (1990).

Murispora bromicola (Phukhams., Ariyaw., Camporesi \& K.D. Hyde) V. Magaña-Dueñas, Cano \& Stchigel, comb. nov. MycoBank MB 835699.

Basionym: Pseudomassariosphaeria bromicola Phukhams., Ariyaw., Camporesi \& K.D. Hyde, Ariyawansa et al., Fungal Diversity: 10.1007/s13225-015-0346-5, [2014] (2015).

Description: Ariyawansa et al. 2015.

Notes: Morphologically differing from the other species of Murispora by its production of hyaline ascospores (brown in the rest of the species of the genus), fusiform to lunate and narrower towards the apex (mostly ellipsoidal with rounded ends in other species), and not strongly constricted at the septa (although strongly constricted at septa in all other species of the genus).

Pseudomassariosphaeria triseptata, of marine origin, is a species recently introduced to the genus Pseudomassariosphaeria by Jones et al., in 2020 [35]. However, in our phylogenetic analysis, this species, as well as P. bromicola, was placed into the Murispora clade. Therefore, we propose the next new combination for this fungus.

Murispora trisepata (E.B.G. Jones \& Abdel-Wahab) V. Magaña-Dueñas, Cano \& Stchigel, comb. nov. MycoBank MB 836493.

Basionym: Pseudomassariosphaeria triseptata E.B.G. Jones et Abdel-Wahab. Botanica Marina 63(2):157 (2020)

Description: Jones et al. 2020.

Notes: Murispora triseptata differs from all other species of the genus by possessing hyaline, 3-septate, ellipsoidal big ascospores [35].

Based on phenotypic features and phylogenetic results, three new species of Murispora are proposed as follows:

Murispora fissilispora V. Magaña-Dueñas, Stchigel \& Cano, sp. nov. FMR 17,251. MycoBank MB 835710 (Figure 3).

Etymology. From Latin fissile-, splitting, and -sporarum, spore, because the ascospores split at the middle when old.

Mycelium superficial to immersed, composed by septate, smooth- and thin-walled, pale brown, branched, 2-3 $\mu \mathrm{m}$ wide hyphae. Ascomata perithecial, immersed to semi-immersed, solitary, dark brown to black, ostiolate, papillate, neck conic-truncate, 105-108 $\times 60 \mu \mathrm{m}$, pyriform, 320-350 × 280-300 $\mu \mathrm{m}$; peridial wall 2-3-layered, 30-60 $\mu \mathrm{m}$ thick, outer wall of textura intricata composed of brown to dark brown hyphae 2-4 $\mu \mathrm{m}$ diam, inner wall layer hyaline and thin; hamathecium comprising numerous hyaline, filamentous, branched, septate paraphyses 1.5-2 $\mu \mathrm{m}$ wide; periphysate; asci 4-8-spored, bitunicate, stipitate, cylindrical to cylindrical-clavate, 160-200 × 14-16 $\mu \mathrm{m}$, stipe 20-25 $\mu \mathrm{m}$ long, without apical structures; ascospores hyaline when young, becoming brown at maturity, muriform, broadly fusiform to irregularly shaped, $15-27 \times 6-8 \mu \mathrm{m}$, surrounded by a mucilaginous sheath, divided at the middle when old due to the narrowing of the medial septum. Conidiomata pycnidial, solitary, mainly immersed, pale brown to brown, ostiolate, subglobose, $65-70 \times 85-90 \mu \mathrm{m}$; conidiomata wall of textura angularis, composed of pale brown to brown, flattened polygonal cells of 4-7 $\mu \mathrm{m}$ diam.; conidiophores reduced to the conidiogenous cells, which are phialidic, hyaline, smooth-walled, formed from the innermost layer of the pycnidial wall; conidia one-celled, hyaline, ovoid to ellipsoidal, 3-4 $\times 1.5-2.5 \mu \mathrm{m}$, guttulate. 


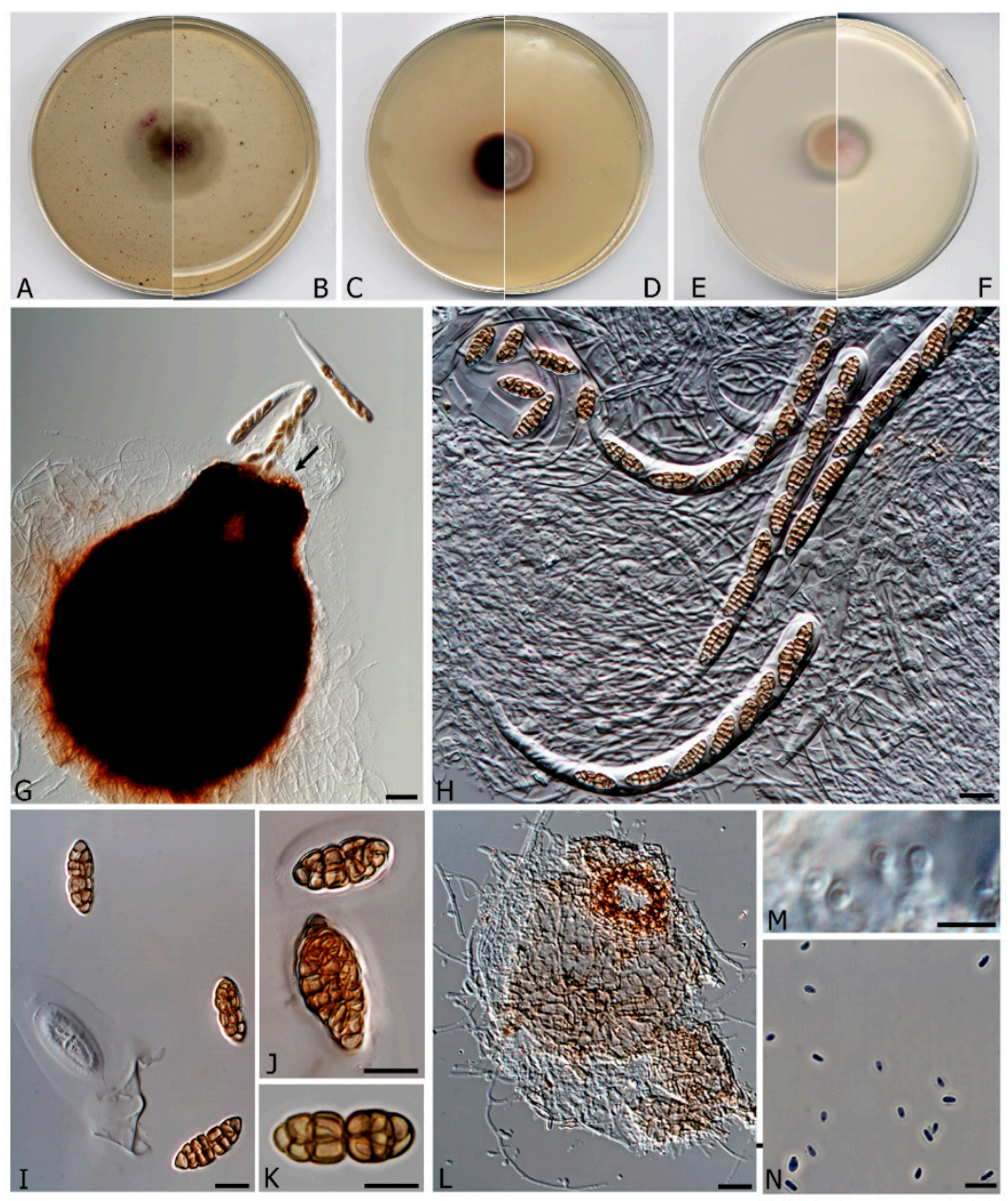

Figure 3. Murispora fissilispora CBS H-24462. (A,B) Colonies on OA (reverse and front), (C,D) MEA $2 \%$ (reverse and front), (E,F) PDA (reverse and front). All media at $15^{\circ} \mathrm{C}$ after 3 weeks. (G) Ascomata expelling asci. (H) Asci. (I-K) Ascospores (Note the mucilaginous sheath in I and J). (L) Pycnidia. (M) Conidiogenous cells. (N) Conidia. Scale bars: $\mathrm{G}=25 \mu \mathrm{m}, \mathrm{H}-\mathrm{N}=10 \mu \mathrm{m}$.

Culture characteristics $\left(3\right.$ weeks at $15{ }^{\circ} \mathrm{C}$ ). Colonies on PDA reaching 20-22 mm diam., convex, floccose, margin regular, with abundant aerial mycelium, surface purplish pink to white (6A2/1A1), border grey (14B1); reverse purplish pink to grey (14A3/14 B 1), diffusible pigment absent. Colonies on MEA $2 \%$ reaching 18-20 mm diam., flattened, velvety, margin regular, greyish brown to dull red (8E3/8C3); reverse reddish brown to greyish red (8F7/7B3), diffusible pigment reddish brown (8D5). Colonies on OA reaching 30-32 mm diam., flattened to slightly floccose, margins regular, with sparse aerial mycelium, deep magenta to purplish grey, with greyish magenta patches (13D8/13D1/13D5), borders white; reverse deep magenta to olive grey with greyish magenta patches $(14 \mathrm{D} 8 / 1 \mathrm{E} 2 / 13 \mathrm{D} 5)$, diffusible absent. Cardinal temperatures of growth: Optimum $15-20^{\circ} \mathrm{C}$, maximum $28^{\circ} \mathrm{C}$, minimum $5{ }^{\circ} \mathrm{C}$.

Material examined: Spain, Tarragona province, Serra del Montsant, from freshwater submerged plant debris, February, 2018, collected by Eduardo Jose de Carvalho Reis, holotype CBS H-24462, culture ex-type FMR 17,251 = CBS 146936 .

Notes: Murispora fissilispora, genetically distinct from its neighboring Murispora asexualis, is the only species of the genus that produces both sexual and asexual morphs in vitro.

Murispora asexualis V. Magaña-Dueñas, Cano \& Stchigel, sp. nov. FMR 17,248. MycoBank MB 835711 (Figure 4). 

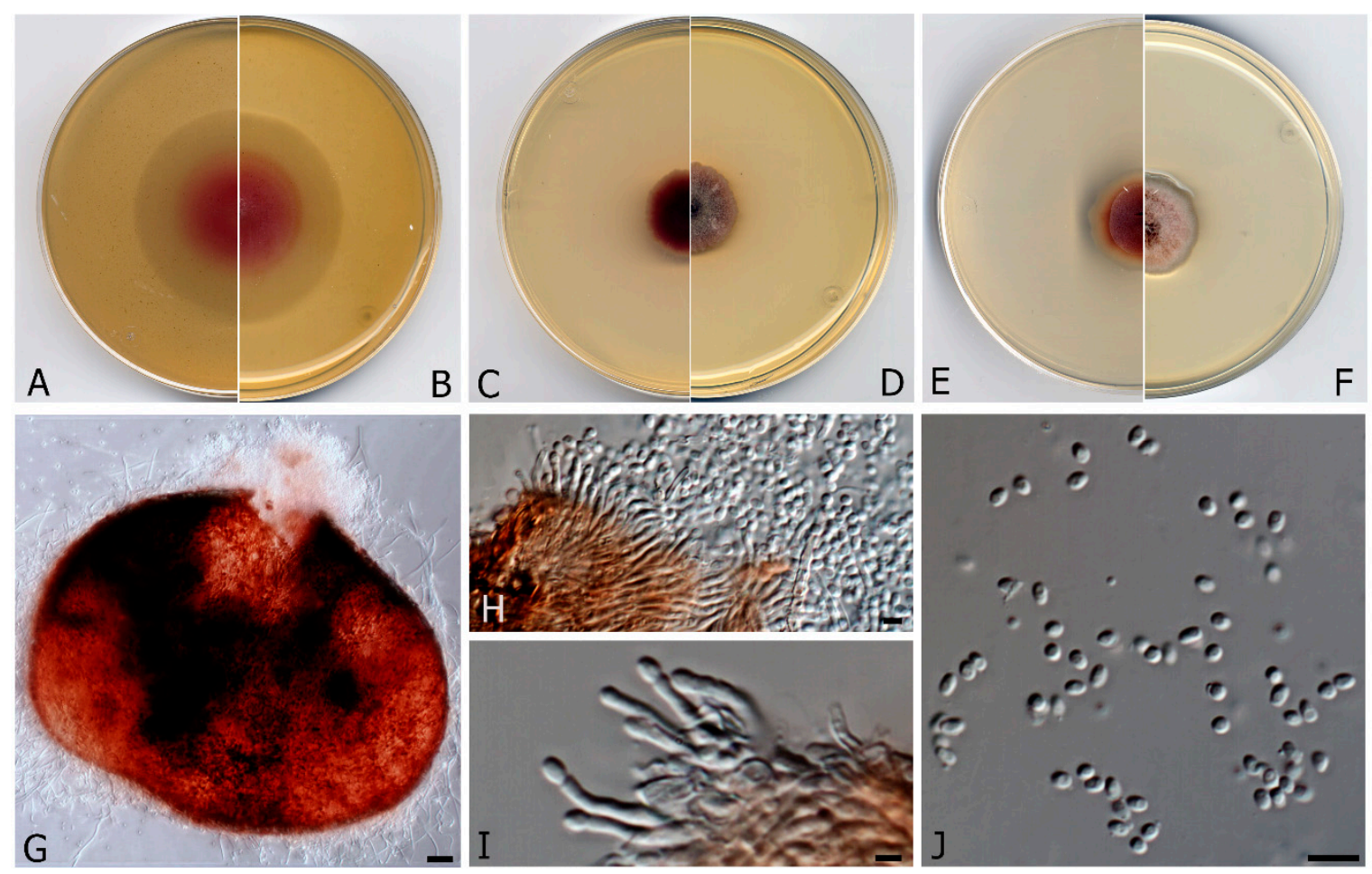

Figure 4. Murispora asexualis CBS H-24463. (A,B) Colonies on OA (reverse and front), (C,D) MEA 2\% (reverse and front), (E,F) PDA (reverse and front). All media at $15{ }^{\circ} \mathrm{C}$ after 3 weeks. (G) Pycnidia $(\mathbf{H}, \mathbf{I})$ Conidiogenous cells $(\mathbf{J})$ Conidia. Scale bars: $(\mathbf{G})=25 \mu \mathrm{m},(\mathbf{H}, \mathbf{J}) 10 \mu \mathrm{m},(\mathbf{I})=2.5 \mu \mathrm{m}$.

Etymology. Because of the lack of a sexual morph, typical of the genus.

Mycelium composed of hyaline, smooth- and thin-walled, septate hyphae, 1.4-1.8 $\mu \mathrm{m}$ wide. Conidiomata pycnidial, solitary, brown to reddish brown, mainly immersed, glabrous, papillate, ostiolate, ovoid, 360-380 × 270-290 $\mu \mathrm{m}$ diam.; peridial wall of textura angularis, 4-6-layered, 20-40 $\mu \mathrm{m}$ thick, composed of brown to dark brown, flattened polygonal cells $3-4 \mu \mathrm{m}$ diam.; conidiophores branched at the base, septate, hyaline to pale brown, straight or sinuous to slightly curved, 7.5-8.5 $\mu \mathrm{m}$ long; conidiogenous cells phialidic, hyaline, smooth- and thin-walled, ampulliform, slightly curved at the apex, 8-11 × 1-2 $\mu \mathrm{m}$; conidia hyaline, non-septate, ovoid, 3-4 $\mu \mathrm{m}$. Sexual morph unknown.

Culture characteristics ( 3 weeks at $15^{\circ} \mathrm{C}$ ). Colonies on PDA, reaching 30-32 mm diam., convex, velvety, margins irregular, with abundant aerial mycelium, surface reddish to white (12A2/1A1) margins grey (12C1); reverse violet brown to reddish brown (10E8/8D8), margins white, diffusible pigment absent. Colonies on MEA $2 \%$ reaching 24-28 mm diam., flattened, floccose, margins irregular, with abundant aerial mycelium, dark ruby to greyish ruby (12F3/12E6), margins reddish grey (12D2); reverse reddish brown to greyish red (8F7/7B3), diffusible pigment reddish brown (8D5). Colonies on OA reaching 38-42 mm diam., margins regular, mycelium mostly immersed, surface pink to yellowish white (12A4/4A2); reverse pink to yellowish white (12A4/4A2), diffusible pigment absent. Cardinal temperature for growth: Optimum $15-20{ }^{\circ} \mathrm{C}$, maximum $30{ }^{\circ} \mathrm{C}$, minimum $5{ }^{\circ} \mathrm{C}$.

Material examined: Spain, Tarragona province, Serra del Montsant, from freshwater submerged plant debris, February, 2018, Eduardo Jose de Carvalho Reis, holotype CBS H-24463, culture ex-type FMR 17,248 = CBS 146937 .

Notes: Murispora asexualis differs morphologically from the phylogenetically nearest species $M$. fissilispora, because it lacks a sexual morph. Furthermore, the conidiophores of $M$. asexualis are branched and slightly curved, while those of $M$. fissilispora are reduced to the conidiogenous cells.

Murispora navicularispora V. Magaña-Dueñas, Stchigel \& Cano, sp. nov. FMR 17,838. MycoBank MB 835712 (Figure 5). 

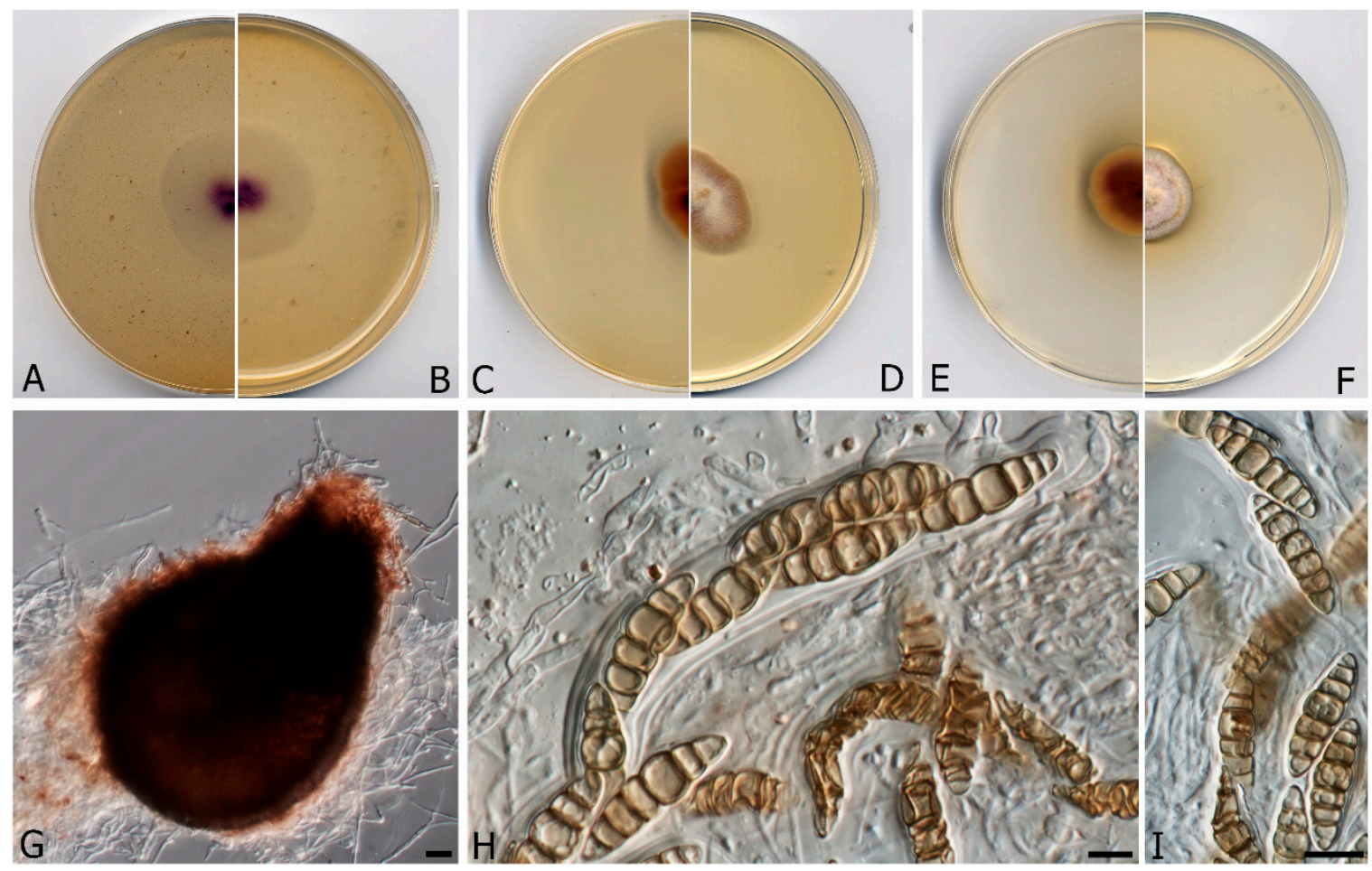

Figure 5. Murispora navicularispora CBS H-24464 (A,B) Colonies on OA (reverse and front), (C,D) MEA $2 \%$ (reverse and front), (E,F) PDA (reverse and front). All media at $15^{\circ} \mathrm{C}$ after 3 weeks. (G) Ascomata. (H) Asci. (I) Ascospores. Scale bars: (G) $=25 \mu \mathrm{m},(\mathbf{H}, \mathbf{I})=10 \mu \mathrm{m}$.

Etymology. From Latin navicularis-, boat-shaped, and -sporarum, spore, because the shape of the ascospores.

Mycelium composed of hyaline, smooth- and thin-walled, septate hyphae, 1.4-1.8 $\mu \mathrm{m}$ wide. Ascomata perithecial, immersed to semi-immersed, solitary, brown to dark brown, ostiolate, papillate, neck conic-truncate, $100-90 \times 60-70 \mu \mathrm{m}$, pyriform, $190-265 \times 160-250 \mu \mathrm{m}$; peridial wall 2-4-layered, 20-50 $\mu \mathrm{m}$ thick, outer wall of textura intricata, composed of hyaline to brown hyphae 1.5-3 $\mu \mathrm{m}$ diam., inner wall composed by hyaline flattened cells; hamathecium comprising numerous hyaline, septate, filamentous, branched paraphyses, periphysate. Asci 8-spored, bitunicate, cylindrical to cylindrical-clavate, 115-120 × 15-20 $\mu \mathrm{m}$, without apical structures. Ascospores 3-7-septate, cinnamon, broadly fusiform to navicular, 21-29 ×6-9 $\mu \mathrm{m}$, narrowing towards the extremes, constricted at the septa, surrounded by a mucilaginous sheath. Natural substrate stained in purple. Asexual form unknown.

Culture characteristics (after 3 weeks at $15^{\circ} \mathrm{C}$ ). Colonies on PDA reaching 25-30 mm diam., umbonate, velvety, slightly cottony center, surface orange white to reddish white (5A2/6A2), pale orange (5A3) at the regular margins; reverse violet brown to yellowish white (10E4/4A2), diffusible pigment orange white (5A3). Colonies on MEA $2 \%$ reaching 26-28 $\times 17-20 \mathrm{~mm}$ diam, ellipsoidal, velvety, convex, white to reddish grey (8B2), with regular margins; reverse reddish brown (8F5), orange white (6A2) at the margins, diffusible pigment absent. Colonies on OA reaching $40-48 \mathrm{~mm}$ diam., flattened, with sparse aerial mycelium, surface and reverse deep violet (15E8), with yellowish white (4A2) regular margins; diffusible pigment absent. Cardinal temperatures of growth: Optimum $15-20{ }^{\circ} \mathrm{C}$, maximum $30{ }^{\circ} \mathrm{C}$, minimum $5{ }^{\circ} \mathrm{C}$.

Material examined: Spain, Sevilla province, Cazalla de la Sierra, Cascadas del Huéznar, from freshwater submerged plant debris, May 2019, collected by José Francisco Cano Lira, holotype CBS H-24464, culture ex-type FMR 17838.

Notes: The fungus produces cinnamon, broadly fusiform to navicular ascospores, features never seen in the genus before.

Lophiostomataceae Sacc. Sylloge Fungorum, 2:672 (1883). MycoBanK 80966. 
Type genus: Lophiostoma Ces. \& De Not., Comm. Soc. crittog. Ital. 1(fasc. 4): 219 (1863). MycoBank MB 2933.

The genus Pseudomassariosphaeria was introduced by Phukhamsakda et al. in 2015 [17], to accommodate Pseudomassariosphaeria bromicola, found in a dead stem of Bromus sterilis L., transferring also Massariosphaeria grandispora to this genus (as Pseudomassariospaheria grandispora). However, in our phylogenetic study P. bromicola is clearly placed into the family Amniculicolaceae (transferred by us to the genus Murispora as M. bromicola earlier in this manuscript), whereas P. grandispora was located in the family Lophiostomataceae, phylogenetically close to Lophiostoma macrostomum and L. arundinis. The placement of P. grandispora into the Lophiostomataceae was previously suggested by Wang in 2007 [36], based on a molecular analysis using $28 \mathrm{~S}$ rDNA, $18 \mathrm{~S}$ rDNA and $r p b 2$ gene. Consequently, we resurrected the name Massariosphaeria grandispora for this fungus.

Massariosphaeria grandispora (Sacc.) Leuchtm., Sydowia 37: 172 (1984). MycoBank MB 114956.

Description: Phukhamsakda et al. 2015.

Basionym: Leptosphaeria grandispora Sacc. Michelia 1(3): 341 (1878).

Synonyms: Lophiotrema grandispora (Sacc.) Shoemaker \& C.E. Babc., Can. J. Bot. 67(5): 1580 (1989). Metasphaeria grandispora (Sacc.) Sacc., Syll. fung. (Abellini) 2: 181 (1883).

Neomassariosphaeria grandispora (Sacc.) Y. Zhang ter, J. Fourn. \& K.D. Hyde, in Zhang, Schoch, Fournier, Crous, Gruyter, Woudenberg, Hirayama, Tanaka, Pointing, Spatafora \& Hyde, Stud. Mycol. 64: 96 (2009).

Pseudomassariosphaeria grandispora (Sacc.) Phukhams., Ariyaw. \& K.D. Hyde, in Ariyawansa et al., Fungal Diversity: 10.1007/s13225-015-0346-5, [17] (2015).

\section{Discussion}

Of the three morpho-ecological groups of freshwater fungi (Ingoldian's, aero-aquatic and facultative) only the latter two were addressed in this study. In our phylogenetic analysis, all of the Amniculicolaceae species clustered in a distinct sister clade to Lindgomycetae, which is similar to previous studies [16-18]. Most Aminiculicolaceae species are reported from freshwater habitats and are widely distributed across Austria, Italy, France, Germany, Denmark, China, Hungary and Spain [15-18,34,37]. However, with exception of Murispora aquatica and M. triseptata (basionym Pseudomassariospaheria triseptata), all species of Murispora were isolated from terrestrial habitats such as dead terrestrial stems and dead and fallen twigs [14-18,35]. In this study, we have introduced three new species of Murispora collected from Spain in freshwater habitats. Thanks to the phenotypic characterization of several fungal isolates and to the subsequent phylogenetic analysis based on a concatenate database of the ITS-LSU-tef1 sequences, we have erected three new species of Murispora: M. asexualis, the unique species of the genus because it lacks a sexual morph; $M$. fissilispora, the first species of this genus to produce a holomorph in vitro, and M. navicularispora, which produces cinnamon-colored, broadly fusiform to navicular ascospores, features never seen in the genus before. In addition, we have proposed the new combinations M. bromicola (formerly P. bromicola) and M. triseptata (formerly P. triseptata), demonstrating that this genus is monophyletic. Consequently, we have enlarged the current concept of Murispora, including species with hyaline, navicular and transversally septate ascospores, or lacking a sexual morph. Our results also indicate that some morphological features, such as the size and shape of the ascospores, have less phylogenetic significance than previously proposed by other authors. Despite Spirosphaera cupreorufescens displaying features considered as typical of that genus, it was phylogenetically distant in our phylogeny (in the class Dothideomycetes) from the type species of the genus (Spirosphaera floriformis, in the class Leotiomycetes), and because S. cupreorufescens formed a strongly supported clade together with two of our strains, we have proposed the erection of the new genus Fouskomenomyces, to include Fouskomenomyces cupreorufescens (the type species of the genus) and the new species Fouskomenomyces mimiticus, both aero-aquatic conidial fungi. Finally, we have also resurrected Massariosphaeria grandispora, because in our phylogeny it was placed into the Lopiostomataceae instead of the Amniculicolaceae. To date, there have been few reports of fungi isolated from freshwater habitats 
in Spain, therefore this work represents an important contribution to the knowledge of the Spanish mycobiota in aquatic environments.

Author Contributions: V.M.-D. performed the experimental work, the phenotypic characterization of the isolates, as well as the DNA extraction and purification, gene sequencing and data processing for phylogenetic analysis, being one of the major contributors of this manuscript. A.M.S., because of their experience with fungal biology and taxonomy, supervised all steps of the experimental work by V.M.-D., collaborating in the description of the novel fungi and in the writing of chapters "Introduction" and "Discussion", reviewing the draft several times. J.F.C.-L. supervised the experimental work too, especially those steps related to nucleotide sequencing of the molecular markers employed in this study, but also the nucleotide sequence alignment and the phylogenetic reconstructions, took the pictures that appear in the figures, contributed actively in the identification and the taxonomy of the fungal strains, gave useful suggestions to write the manuscript and reviewed the draft several times. All authors have read and agreed to the published version of the manuscript.

Funding: This work was supported by the Spanish Ministerio de Economía y Competitividad, grant CGL2017-88094-P.

Acknowledgments: We thank Juan Ramón García Martínez (a non-professional mycologist from Granja de Torrehermosa, Badajoz, Spain) for collaborating in the Sierra Norte de Sevilla sampling. We also thank Phil Hoddy for editing and proofreading the final text.

Conflicts of Interest: The authors declare no conflict of interest. The funders had no role in the design of the study; in the collection, analyses, or interpretation of data; in the writing of the manuscript, or in the decision to publish the results.

\section{References}

1. Grossart, H.; Van den Wyngaert, S.; Kagami, M.; Wurzbacher, C.; Cunliffe, M.; Rojas-Jimenez, K. Fungi in aquatic ecosystems. Nat. Rev. Microbiol. 2019, 17, 339-354. [CrossRef] [PubMed]

2. Shearer, C.A.; Descals, E.; Kohlmeyer, B.; Kohlmeyer, J.; Marvanová, L.; Padgett, D.; Porter, D.; Raja, H.A.; Schmit, J.P.; Thorton, H.A.; et al. Fungal biodiversity in aquatic Habitats. Biodivers. Conserv. 2007, 16, 49-67. [CrossRef]

3. Gessner, M.O.; Gulis, V.; Kuehn, K.A.; Chauvet, E.; Suberkropp, K. Fungal decomposers of plant litter in aquatic ecosystems. In Environmental and Microbial Relationships. The Mycota, 2nd ed.; Kubicek, C.P., Druzhinina, I.S., Eds.; Springer: Heidelberg/Berlin, Germany, 2007; Volume 4, pp. 301-324.

4. Webster, J. Experiment with spores of aquatic hyphomycetes: I Sedimentation, and impaction on smooth surfaces. Ann. Bot. 1959, 23, 595-611. [CrossRef]

5. Wurzbacher, C.M.; Bärlocher, F.; Grossart, H.P. Fungi in lake ecosistems. Aquat. Microb. Ecol. 2010, 59, 125-149. [CrossRef]

6. Dhanasekaran, V.; Jeewon, R.; Hyde, K.D. Molecular Taxonomy, origins and evolution of freshwater ascomycetes. Fungal. Divers. 2006, 23, 351-390.

7. Gareth Jones, E.B. Form and function of fungal spore appendages. Mycoscience 2006, 47, 167-183. [CrossRef]

8. Shearer, C.A.; Raja, H.A.; Miller, A.N.; Nelson, P.; Tanaka, K.; Hirayama, K.; Marvanová, L.; Hyde, K.D.; Zhang, Y. The molecular phylogeny of freshwater Dothideomycetes. Stud. Mycol. 2009, 64, 145-153. [CrossRef]

9. Pang, K.L.; Abdel-Wahab, M.A.; Sivichai, S.; El-Sharouney, H.M.; Gareth Jones, E.B. Jahnulales (Dothideomycetes, Ascomycota): A new order of lignicolous freshwater ascomycetes. Mycol. Res. 2002, 106, 31-42. [CrossRef]

10. Raja, H.A.; Tanaka, K.; Hirayama, K.; Miller, A.N.; Shearer, C.A. Freshwater ascomycetes: Two new species of Lindgomyces (Lindgomycetaceae, Pleosporales, Dothideomycetes) from Japan and USA. Mycologia 2011, 103, 1421-1432. [CrossRef]

11. Raja, H.A.; Paguigan, N.D.; Fournier, J.; Oberlies, N.H. Additions to Lindgomyces (Lindgomycetaceae, Pleosporales, Dothideomycetes), Including two new species occurring on submerged wood from North Carolina, USA, with notes on secondary metabolite profiles. Mycol. Prog. 2017, 16, 535-552. [CrossRef]

12. Raja, H.A.; Miller, A.N.; Shearer, C.A. Freshwater ascomycetes: Natipusillaceae, a new family of tropical fungi, including Natipusilla bellaspora sp. nov. from the peruvian Amazon. Mycologia. 2012, 104, 569-573. [CrossRef] [PubMed] 
13. Zhang, Y.; Jeewon, R.; Fournier, J.; Hyde, K.D. Multi-Gene phylogeny and morphotaxonomy of Amniculicola lignicola: A Novel Freshwater Fungus from France and Its Relationships to the Pleosporales. Mycol. Res. 2008, 112, 1186-1194. [CrossRef] [PubMed]

14. Zhang, Y.; Fournier, J.; Crous, P.W.; Pointing, S.B.; Hyde, K.D. Phylogenetic and morphological assessment of two new species of Amniculicola and their allies (Pleosporales). Pers. Mol. Phylogeny Evol. Fungi 2009, 23, 48-54. [CrossRef] [PubMed]

15. Zhang, Y.; Schoch, C.L.; Fournier, J.; Crous, P.W.; de Gruyter, J.; Woudenberg, J.H.C.; Hirayama, K.; Tanaka, K.; Pointing, S.B.; Spatafora, J.W.; et al. Multi-locus phylogeny of Pleosporales: A taxonomic, ecological and evolutionary Re-evaluation. Stud. Mycol. 2009, 64, 85-102. [CrossRef]

16. Wanasinghe; Dhanushka, N.; Gareth Jones, E.B.; Camporesi, E.; Mortimer, P.E.; Xu, J.; Bahkali, A.H.; Hyde, K.D. The Genus Murispora. Cryptogam. Mycol. 2015, 36, 419-448. [CrossRef]

17. Ariyawansa, H.A.; Hyde, K.D.; Jayasiri, S.C.; Buyck, B.; Chethana, K.W.T.; Dai, D.Q.; Dai, Y.C.; Daranagama, D.A.; Jayawardena, R.S.; Luecking, R.; et al. Fungal Diversity Notes 111-252-Taxonomic and phylogenetic contributions to fungal taxa. Fungal Divers. 2015, 75, 27-274. [CrossRef]

18. Bao, D.; Wanasinghe, D.; Luo, Z.; Mortimer, P.E.; Kumar, V.; Su, H.; Hyde, K.D. Murispora aquatica sp. nov. and Murispora fagicola, a new record from freshwater habitat in China. Pytotaxa 2019, 416, 1-13. [CrossRef]

19. Samson, R.A.; Houbraken, J.; Thrane, U.; Frisvad, J.C.; Andersen, B. Food and Indoor Fungi, 2nd ed.; CBS Laboratory Manual Series; CBS-KNAW Fungal Biodiversity Centre: Utrecht, The Netherlands, 2010; p. 390.

20. Hawksworth, D.L.; Kirk, P.M.; Sutton, B.C.; Pegler, D.N. Ainsworth \& Bisby's Dictionary of the Fungi, 8th ed.; CAB International: Oxon, UK, 1995; p. 616.

21. Kornerup, A.; Wanscher, J.H. Methuen Handbook of Colour, 3rd ed.; Methuen: London, UK, 1978; p. 256.

22. Chupp, C. Further notes on double cover-glass mounts. Mycologia 1940, 32, 269-270. [CrossRef]

23. Rehner, S.A.; Samuels, G.J. Taxonomy and Phylogeny of Gliocladium Analysed from Nuclear Large Subunit Ribosomal DNA Sequences. Mycol. Res. 1994, 98, 625-634. [CrossRef]

24. Vilgalys, R.; Hester, M. Rapid Genetic Identification and Mapping of Enzymatically Amplified Ribosomal DNA from Several Cryptococcus Species. J. Bacteriol. 1990, 172, 4238-4246. [CrossRef]

25. White, T.J.; Bruns, T.; Lee, S.J.W.T.; Taylor, J. Amplification and direct sequencing of fungal ribosomal RNA genes for phylogenetics. In PCR Protocols: A Guide to Methods and Applications, 1st ed.; Innis, M.A., Gelfand, D.H., Sninsky, J.J., White, T.J., Eds.; Academic Press: San Diego, CA, USA, 1990; pp. 315-322.

26. Rehner, S. Primers for Elongation Factor 1- $\alpha$ (EF1- $\alpha)$. 2001. Available online: http://ocid.NACSE.ORG/ research/deephyphae/EF1primer.pdf. (accessed on 2 February 2020).

27. Kumar, S.; Stecher, G.; Tamura, K. MEGA7: Molecular Evolutionary Genetics Analysis Version 7.0. for Bigger Datasets. Mol. Biol. Evol. 2016, 33, 1870-1874. [CrossRef] [PubMed]

28. Thompson, J.D.; Higgins, D.G.; Gibson, T.J. CLUSTAL W: Improving the sensitivity of progressive multiple sequence alignment through sequence weighting, position-specific gap penalties and weight matrix choice. Nucleic. Acids. Res. 1994, 22, 4673-4680. [CrossRef] [PubMed]

29. Edgar, R.C. MUSCLE: Multiple sequence alignment with high accuracy and high throughput. Nucleic. Acids. Res. 2004, 32, 1792-1797. [CrossRef]

30. Stamatakis, A. RAxML Version 8: A tool for phylogenetic analysis and post-analysis of large phylogenies. Bioinformatics 2014, 30, 1312-1313. [CrossRef] [PubMed]

31. Miller, M.A.; Pfeiffer, W.; Schwartz, T. The CIPRES science gateway: Enabling High-Impact science for phylogenetics researchers with limited resources. In Proceedings of the 1st Conference of the Extreme Science and Engineering Discovery Environment: Bridging from the Extreme to the Campus and Beyond, Chicago, IL, USA, 16 July 2012; Association for Computing Machinery: New York, NY, USA, 2012; pp. 1-8.

32. Ronquist, F.; Teslenko, M.; Van Der Mark, P.; Ayres, D.L.; Darling, A.; Höhna, S.; Larget, B.; Liu, L.; Suchard, M.A.; Huelsenbeck, J.P. Mrbayes 3.2: Efficient bayesian phylogenetic inference and model choice across a large model space. Syst. Biol. 2012, 61, 539-542. [CrossRef]

33. Posada, D. JModelTest: Phylogenetic model averaging. Mol. Biol. Evol. 2008, 25, 1253-1256. [CrossRef]

34. Voglmayr, H. Spirosphaera cupreorufescens sp. nov., a rare aeroaquatic fungus. Stud. Mycol. 2004, 50, $221-228$.

35. Gareth Jones, E.B.; Devadatha, B.; Abdel-Wahab, M.A.; Dayarathne, M.C.; Zhang, S.N.; Hyde, K.D.; Liu, J.K.; Bahkali, A.H.; Sarma, V.V.; Tibell, S.; et al. Phylogeny of New Marine Dothideomycetes and Sordariomycetes from Mangroves and Deep-Sea Sediments. Bot. Mar. 2020, 63, 155-181. [CrossRef] 
36. Wang, H.K.; Aptroot, A.; Crous, P.W.; Hyde, K.D.; Jeewon, R. The Polyphyletic Nature of Pleosporales: An Example from Massariosphaeria Based on RDNA and RBP2 Gene Phylogenies. Mycol. Res. 2007, 111, 1268-1276. [CrossRef]

37. Hernández-Restrepo, M.; Gené, J.; Castañeda-Ruiz, R.F.; Mena-Portales, J.; Crous, P.W.; Guarro, J. Phylogeny of saprobic microfungi from Southern Europe. Stud. Mycol. 2017, 86, 53-97. [CrossRef]

(C) 2020 by the authors. Licensee MDPI, Basel, Switzerland. This article is an open access article distributed under the terms and conditions of the Creative Commons Attribution (CC BY) license (http://creativecommons.org/licenses/by/4.0/). 